\title{
THE EXISTING COURT-MARTIAL SYSTEM AND THE ANSELL ARMY ARTICLES
}

\author{
EdMund M. Morgan \\ Professor of Law, Yale University
}

Our present military code has come to us without fundamental change from the British Articles of War of 1765 , which owed their origin to Rome. ${ }^{1}$ Whether or not this may tend to account for the remarkable indefiniteness of the punitive $\operatorname{articles}^{2}$ or help to explain

${ }^{1}$ The original code was enacted June 30,1775 ; many of its articles were copied from the Articles adopted April 5, 1775, by the provisional Congress of Massachusetts Bay, undoubtedly derived from the then existing British articles. This code was amended by resolution of November 7, 1775, and on September 20 , 1776 , was superseded by articles, as to the origin of which, John Adams says :

"Mr. Adams and Mr. Jefferson were appointed a committee to hear Tudor and to revise the articles. . . . There was extant one system of articles of war, which had carried two empires to the head of command, the Roman and the British, for the British Articles of war were only a literal translation of the Roman. . . . I was therefore for reporting the British articles totidem verbis. : - The British articles were accordingly reported." 3 Charles F. Adams, Works of John Adams (1850) 93.

In the case of William T. Smithson, Ops. J. A. G., R. 5, 29I, Nov. I3, I863, Holt, Judge Advocate Genera1, said:

"In this respect (i. e. repression of communications with the enemy), as in most others, our articles of war were with slight exceptions, copied from those of Great Britain, while the latter were in their turn but a translation of the Roman Code, which had inspired a discipline that achieved the conquest of the world."

The articles of 1776 and amendments thereto were continued in force, so far as "applicable to the Constitution of the United States," by the Act of April 20,1790 , and by subsequent enactments until 1806 , when they were repealed and new articles adopted, which, however, made no fundamental changes. The code enacted June 22, I874; was substantially the Code of I806, as eighty-seven of the one hundred and one articles which made up that code survived therein unchanged, and a considerable number of the remaining articles survived without substantial change. Gen. E. H. Crowder, Report of Hearing before the Committee on Military Affairs, House of Representatives, 62d Cong. $2 \mathrm{~d}$ sess., on H. R. 23628, I6. The present articles, adopted August 29, 1916, constitute a rearrangement and reclassification of previously existing law without substantial change. 39 Stat. at L. 650-670. See Crowder, ibid., 43, 47ff; Manual for Courts-Martial, Intro.; I Winthrop, Military Law (1886) 4-I5; 2 ibid., 40-I25; Comparison of Proposed New Articles of War with the Present Articles of War and Other Related Statutes (rg̀rz). Comparative Print showing S. 3IgI etc. 64th Cong., Ist sess., Senate Committee Print.

${ }^{2}$ The capital offenses, mutiny and desertion, are not defined. The formerly accepted definition of desertion has been broadened by interpretation during

[52] 
some of the procedural peculiarities of the system, ${ }^{3}$ the fact remains that many of the concepts of the existing law military are so foreign to American jurisprudence as to startle and perplex the American lawyer. The usual tribunal for the trial of military offenses is the court-martial, which is of three kinds, namely, general, special, and summary. The general court consists of from five to thirteen officers, the special, of from three to five officers, and the summary, of one officer. Their appointment is vested, as an attribute of command, 5 in superior military authority designated by statute. The appointing authority may name a court for the trial of a particular case or for the trial of such cases as may be properly referred to it. The jurisdiction of special and summary courts is limited as to person, as to subject matter, and as to punishments imposable. ${ }^{b}$ To attempt to explain the court-martial system, the respective functions of appointing authority, court, judge advocate and counsel, by analogies to the American system of administering criminal justice in the civil courts, would serve only to mislead. But since the object of a military trial is to determine, by a supposedly impartial investigation, the guilt or innocence of the accused, who is accorded the same presumption of

the late war. Military writers are in great conflict over the proper definition of mutiny. In a review of a case in the office of the Judge Advocate General in the spring of 1919, the following occurs:

"From the dozen or so of authoritative writers on Military Law it may be deduced: That mutiny is of necessity a collective offense; that it is not necessarily a collective offense, but can be committed by a single individual; that the resistance or opposition to authority may be purely passive; that the resistance or opposition must be more than passive, since it requires concert of action and a purpose to usurp, subvert, over-ride or neutralize lawful authority; that there must be resistance, cpposition, or defiance to superior authority; that there need not be opposition, resistance or defiance, but only insubordination or such murmuring or muttering as tends to create dissatisfaction. Out of this welter nothing can be gotten, and no recourse seems available except to glean from the precedents of this office such a definition as will, on the one hand distinguish the high crime of mutiny from petty insubordination by individuals, punishable as such, and on the other, avoid the exacting and unnecessary requirements of the maritime law."

There is similar indefiniteness as to the other offenses. The scope of the 96th A. W. is almost unlimited. Punishments are not definitely prescribed and limited.

${ }^{3}$ See Page, Military Laz-A Comparative Study (I9I9) 32 HaRv. L. REv. 349373.

'As to the history and functions of the Military Commission, see 2 Winthrop, op. cit., $57 \mathrm{ff}$. Whether Col. Winthrop is correct in attributing the creation of the Military Commission in this country to General Scott, and in classifying certain earlier tribunals as special courts-martial, may well be doubted. As to Provost Courts, see Mechanics' and Traders' Bank v. Union Bank, (1874, U. S.) 22 Wall. 276, 30r. As to Courts of Inquiry, see Manual for Courts-Martial, pars. $447-475$.

"Manual for Courts-Martial, par. I8.

${ }^{\circ}$ A. W. I3, I4. The A. W. are found in U. S. Rev. St. sec. 3, as amended by Act of August 29, I916; 39 Stat. at L. 650-670. 
innocence as in non-military courts, certain obvious questions obtrude themselves. By what procedure is the charge preferred, and the accused brought to trial? What guaranties exist of the impartiality of appointing authority and court? What provisions are made to assure a fair and impartial presentation of the facts and the applicable law? To what extent and in what respects is the court subject to the control of the appointing and other superior military authority? Are the proceedings subject to review for the correction of errors?

The procedure for preferring charges and bringing the accused to trial is prescribed almost exclusively by regulations, and the customs of the service. The only applicable statutory provision is the 7oth Article of War. This requires that a copy of the charges upon which an accused is to be tried shall be served upon him within eight days after arrest, and that he be brought to trial within ten days after arrest, ${ }^{7}$ unless the necessities of the service prevent such trial, in which case he must be brought to trial within thirty days after the expiration of said ten days. If the charges are not so served or the trial not so had, the Article provides that the arrest shall cease. These provisions have been more honored in the breach than in the observance, ${ }^{8}$ for the arrest does not automatically terminate upon the expiration of the prescribed period, but must be lifted upon proper application to proper military authority. ${ }^{9}$ Where the arrest is accompanied by confinement, relief therefrom might be had by a resort to habeas corpus proceedings.10 Release from arrest does not affect a subsequent prosecution for the same offense. ${ }^{11}$

By the customs of the service, charges may be initiated by any one, but they may be preferred only by a commissioned officer. ${ }^{12}$ The Manual for Courts-Martial has long provided in general terms for a careful investigation of charges before reference thereof for trial.13 Experience during the late war demonstrated the insufficiency of this requirement to prevent hasty or ill-guarded action by officers exercising general court-martial jurisdiction, and the reference of trivial or ill-founded charges to general courts. ${ }^{14}$ This caused the Judge

\footnotetext{
"Ops. J. A. G. 250. 3, Feb. 25, I918.
}

${ }^{8}$ See statistics in Dig. Ops. J. A. G. April, Igr8, 35 ; Comparative Print showing S. 3Igr etc. 64th Cong. Ist sess., Senate Committee Print, 42, sec. (b).

${ }^{\circ}$ I Winthrop, op. cit., I5I; Davis, Military Law (3d ed. I913) 64; Dig. Ops. J. A. G. Igr2, I53.

${ }^{20}$ See Richard Blake's Case (I8I4, K. B.) 2 Man. \& Sel. 428; Wales v. Whitney (I885) II4 U. S. 564, 57I, 5 Sup. Ct. I050.

${ }^{11} \mathrm{I}$ Winthrop, op. cit., 36r.

${ }^{12}$ Manual for Courts-Martial, pars. 62, 63.

${ }^{13}$ Ibid., par. 76.

" See C. M. No. I0I776, where a soldier was tried by a general court upon the single charge of stealing two cans of condensed milk of the alleged value of fourteen cents. He was found guilty and sentenced to three months confinement. In C. M. No. I24I3I a soldier in sick quarters took \$3.10 out of 
Advocate General to recommend amendments which would lay down with particularity the duties and responsibilities of investigating officers, and require officers exercising general court-martial jurisdiction to obtain and consider the written opinion of a staff judge advocate before ordering a charge to be tried by a general court. ${ }^{16}$ This recommendation resulted in the promulgation under date of July I4, I9I9, of Changes No. 5 of the Manual for Courts-Martial, which modified paragraph 76 and inserted paragraph $76 a^{16}$ so as to re-

the pocket of a pair of trousers hanging upon the wall. He left the room; within a few minutes he became conscience-stricken and forthwith returned the money. He was tried by general court and sentenced to dishonorable discharge and confinement for one year. In C. M. No. I23I80 accused was tried by a general court for his refusal to obey the command of a sergeant to take off a bow tie and for using foul and abusive language to the sergeant after being put in arrest by the sergeant's order. He was found guilty and sentenced to twenty-five years imprisonment, which the appointing authority on review reduced to ten years.

${ }^{15}$ Memo. April 4, 19I9. No doubt, this recommendation and the subsequent action of the War Department thereon were influenced by the then pending agitation for court-martial reform through Congressional action.

10 "The officer immediately exercising summary court-martial jurisdiction over the command to which the accused belongs or pertains, will, when a charge is received by him, examine it carefully for the purpose of determining whether it states an offense cognizable by a military tribunal and whether it is laid under the proper Article of War and will, when necessary, cause or permit a charge to be amended or a new or additional charge to be preferred. If, in his opinion, any charge is trivial or inconsequential, he will dispose of it without trial by court-martial. Where the case presented is one which, in his opinion, should be disposed of under the one-hundred and fourth article of war, he himself will so dispose of it $\mathrm{He}$ may, without further investigation, refer the charges to a summary court-martial for trial. If he believes that the charges should be tried by a special or a general court-martial, he will, before taking further action thereon, either carefully investigate them himself, or cause them to be investigated by an officer, other than the one preferring the charges, whose rank, experience and qualifications are such as to fit him for the performance of this important duty. The officer investigating the charges will afford the accused an opportunity to make any statement, call any witness, offer any evidence, or present any matter in explanation or extenuation of his alleged offense that he may desire to have considered. He will, at the outset of his investigation, carefully warn the accused that it is not necessary for him to make any statement with reference to the charges against him, but that if he does make one, it may be used against him. (See par. $225(b)$.) The accused will not be interrogated without the consent of his counsel. All material testimony given by any witness in person will be reduced to a clear, succinct statement which should be read to the witness and signed by him. When it is not practicable to obtain personal testimony from any material witness, either for the prosecution or the defense, a written statement will be obtained, if possible, by the officer investigating the charges, of the testimony to be expected from such witness and submitted with the report of investigation. He will also submit available papers or documents which may serve to throw light on the case. Any written statement made by the accused will be read over to him and he will be offered an opportunity to sign it, if he so desires, but he will not be required to do so and will be advised that it is not necessary for him to do so. Care will be taken to insure that the accused is fully advised of the nature of the offense charged against him and of his legal rights in the premises.

"The investigating officer will submit his report to the authority appointing him, inclosing papers, documents, and the signed statements of witnesses referred to above, in the form of an indorsement on the letter of transmittal submitted with the charges by the preferring officer. The report will include a reference to any known document or other matter of evidence not inclosed but which may become important or necessary in the case. It will also include a statement 
quire a careful scrutiny of all charges for defects in form and substance and a thorough investigation thereof to determine the necessity or advisability of trial. Upon the officer exercising immediate summary courtmartial jurisdiction over the accused is enjoined the duty of examining the charges with great care, and to dispose of them without trial when practicable. If he decides that trial by a special or general court is advisable, he must cause a thorough investigation to be made by a competent officer, who must maintain an attitude of judicial fairness and be vigilant to see that the accused is not misled or deceived to his prejudice. No case is to be referred to a general court, until the charges and evidence supporting them have been examined by a staff judge advocate, whose duty it is to cause all amendable defects to be corrected and thereafter to advise the appointing authority

"that they are correct in form and appropriate to the indicated competent evidence in the case, and whether or not, in the opinion of the judge advocate, a prima facie case justifying trial, exists."

It will be observed that charges must be preferred and tried within a prescribed period after the arrest, that violation of this requirement does not affect the liability of the accused to later trial for the same offense, but gives him only the right to release from arrest upon proper application; that charges may be preferred only by a commissioned officer; that the preliminary investigation, while directed

of all explanatory or extenuating circumstances which shall have come to the attention of the investigating officer, a statement as to whether he believes the charges can be sustained, and a specific recommendation as to the disposition thereof. An officer charged with the important duty of investigating charges for trial by court-martial will maintain throughout such investigation an attitude of judicial fairness, the object of his investigation being to prevent unjust or unnecessary trials quite as much as to establish the existence of facts upon which the accused may properly be brought to trial. When the officer immediately exercising summary court-martial jurisdiction over the command to which the accused belongs or pertains is the officer preferring the charges, he will cause them to be investigated by some officer, other than himself, before reaching a decision as to their disposition, except where he decides to refer them for trial to a summary court. When the officer preferring the charges is the only officer with the command, and is of the opinion that the case is one for a special or general court-martial, he will himself investigate the charges and make the report thereof as just described.

"From this investigation the officer immediately exercising summary courtmartial jurisdiction over the command to which the accused belongs or pertains will decide what disposition is to be made of the charges against him. Unless such officer is the accuser or prosecutor of the person to be tried, he should not ordinarily forward charges to superior authority, except in cases where he desires to recommend trial by a court-martial not within his competency to appoint; all other cases he should dispose of without reference to higher authority. Action forwarding charges to superior authority will be in the form of an indorsement on the letter of transmittal submitted by the officer preferring the charges, following the report of investigation. The letter of transmittal, together with all indorsements thereon, will be referred with the charges to the trial judge advocate for his information in preparing the case for trial, but neither this document, nor any part thereof, will be shown to the court or any member thereof. In case of trial by general court-martial, the letter of transmittal with all indorsements thereon will be forwarded to the Judge Advocate General with the record of trial.

"Each commanding officer superior to the one immediately exercising summary 
to be thorough, does not take the form of a hearing: at which prosecutor and accused are or may be represented, and that while the advice of a law officer upon the sufficiency of the charge and of the evidence must be obtained, it need not be followed by the officer with authority to refer the case for trial.

The guaranties of impartiality of appointing authority and court seem to the civilian lawyer altogether inadequate. It is true that since the Act of May 3, I83o, an officer who is accuser or prosecutor of the person to be tried is incompetent to appoint a general or special court for such trial. ${ }^{17}$ But there is no other provision disqualifying the appointing authority for actual or constructive bias or prejudice. In like manner, an officer who is the accuser or a witness for the prosecution is ineligible by statute to sit upon a general or special court. ${ }^{18}$ And no officer may, when it can be avoided, be inferior in rank to the accused. ${ }^{19}$ Members of such courts are subject to challenge for cause stated, but a challenge may be interposed to only one

court-martial jurisdiction over the accused into whose hands charges may officially come will either refer them to a court-martial within his jurisdiction for trial, forward them to the next superior authority exercising court-martial jurisdiction over the command to which the accused belongs or pertains, or otherwise dispose of them as circumstances may appear to require." Manual for Courts-Martial, par. 76 .

"Before directing the trial of any charge by general court-martial or military commission, the convening authority will refer it to his staff judge advocate for consideration. Should the investigation of the charges appear not to be complet and satisfactory, the charges may be returned for further investigation, to be conducted, reported, considered, and acted upon in like manner as the original investigation; or, in a proper case, the necessary further investigation may, when practicable, be conducted by the staff judge advocate, and inspector or other suitable officer through direct correspondence or personal interview. Should any charge or specification appear to be improperly drawn, the staff judge advocate may secure its correction or the substitution of another through direct correspondence or personal interview. The staff judge advocate may, over the signature of the officer perferring the charges, make corrections in the phraseology of any charge or specification, by addition, substitution, or elimination, whenever such correction does not change the substantive character of the charge or specification, as preferred by the officer signing it. He may also properly cause new or substituted specifications and charges, based upon the indicated competent evidence, to be preferred. When these charges are returned by the staff judge advocate to the convening authority, he should advise the latter that they are correct in form and appropriate to the indicated competent evidence in the case, and whether or not, in the opinion of the judge advocate, a prima facie case justifying trial, exists. The duties herein prescribed for a staff judge advocate will be performed by the officer acting as such if no judge advocate is on duty on the staff of the convening authority." Mameal for Courts-Martial, par. $76 \mathrm{a}$.

${ }^{17}$ In G. O. No. 9, W. D. March 13, I830, the proceedings in the court-martial case of Col. R. Jones, Adjutant General, were published. It appeared therefrom that Major General Macomb prepared the charges, appointed the court, appeared as the prosecuting witness at the trial, and as reviewing authority approved the conviction and sentence. On May 30 following, an amendment to the then 65th A. W. enacted the prohibition found in the 8th and 9th Articles of the present code.

${ }^{18}$ A. W. 8, 9. For tests to determine when an officer is accuser or prosecutor, see Manial for Courts-Martial, par. I7; I Winthrop, op. cit., 68-70; C. M. No. 105636 Sept., I9I7; C. M. No. II5526 June, Igr8.

${ }^{10}$ A. W. 16 . 
member at a time, and the relevancy and validity of such challenge are determined by the remaining members of the court. ${ }^{20}$ There is, then, no provision for special triers or for a challenge to the array. Thus, where $A$ and $B$ are charged separately and tried separately for having jointly committed an offense, and where the evidence in each case will be substantially the same as in the other, members who sat at the trial of the first case are obviously unfitted to try the second fairly and impartially; yet only one officer may be challenged at a time. It results that when one member is challenged in the second case upon the ground that he is biased by reason of having sat on the first case, the challenge must be decided by the other members, who will be subject to exactly the same challenge and who, in passing upon any particular challenge, must necessarily pass upon their own qualifications to sit in the second case. Finally, neither the private nor the noncommissioned officer is eligible to be a member of a court, regardless of the grade or rank of the accused. ${ }^{21}$

The provisions for assuring a fair and thorough presentation of the facts and the applicable law at the trial impress the common-law practitioner as inapt and insufficient. Besides the reporter, the accused and the witnesses, the functionaries at the trial are the court, the trial judge advocate, and in some cases his assistant, and counsel for the accused. The case is, in all its essentials, a criminal prosecution. The rules of evidence are those of the Federal courts as modified by Presidential regulations, found generally in the Manual for CourtsMartial. The offense alleged is a violation of one or more of the punitive articles of war, which, as before intimated, are of unusual indefiniteness. The functions of the court are to rule upon all questions of law and fact arising at the trial, including the admissibility of proffered evidence, to weigh all evidence duly admitted, and to reach an impartial decision thereon according to law. The duties of the trial judge advocate are to present the case for the prosecution, to act as legal adviser to the court and, where accused has no counsel, to inform him of his legal rights. Counsel for accused is charged with the protection of the rights and interests of the accused like counsel for the defence in the ordinary criminal action.

To these difficult and technical tasks, what skill, learning and experience are these functionaries required to bring? None, save those necessarily attached to the status of a commissioned officer of the Army. No member of the court need be learned in the law or skilled in the

\footnotetext{
${ }^{\circ}$ A. W. I8; Manual for Courts-Martial, par. I25. A summary court officer is not subject to challenge.

${ }_{21}$ This is approved in the Report of the Majority of the Special Committee on Military Law of the American Bar Association (I9I9) 38-40. In the minority report of the same committee a court in which all members but the president shall be soldiers is recommended for the trial of soldiers.
} 
investigation of facts. ${ }^{22}$ On July I4, I9I9, paragraph 6 of the Manual for Courts-Martial was amended, so as to advise appointing authorities

"that a majority of officers appointed on a general court-martial should have not less than a total of two years service. . . when such officers can be detailed without manifest injury to the service,"

and that care should be taken "to select those officers of the command who are best qualified for such duty by training and experience." None but these meagre qualifications are demanded of these officers who are to perform all the duties of ruling upon evidence and interpreting statutes and orders ordinarily performed by the Federal District court in the trial of a criminal cause.

The trial judge advocate may be and usually is of less learning and experience than the members of the court. $\mathrm{He}$ is usually a line officer of comparatively low rank. Present regulations direct that where it can be avoided, no officer who has not had experience as a member and as an assistant judge advocate of a court-martial, shall be detailed as judge advocate of a general court. ${ }^{23}$ No further qualifications are prescribed.

The present 17 th Article of War specifically provides that the accused shall have the right to be represented before the court by counsel of his own selection for his defence, if such counsel be reasonably available. This is the first statutory enactment requiring counsel to be furnished the accused. The goth Article of the Code of 1874 made no such provision but prescribed that the judge advocate should so far consider himself counsel for the prisoner as to object to leading questions and to any question put to the prisoner, the answer to which might tend to incriminate him. The 69 th Article of the Code of 1806 had a similar stipulation. General Order No. 29 of the year I8go required the commanders of posts where courts-martial were convened to detail, if practicable, at the request of the accused, a suitable officer as his counsel. Long prior thereto, it was customary for the accused to have at his side a friend or adviser, who, however, had no official standing in court, and was heard, if at all, only as a matter of grace. ${ }^{24}$ Finally, on July I4, I9I9, paragraph 108 of the Manual for Courts-Martial was amended by adding the following paragraph:

"Every officer convening a general or special court-martial will, in the convening order, detail a defence counsel for the court whose duty

\footnotetext{
$\approx$ In some instances, the ignorance of the court upon fundamentals is ludicrous, as, for example, in C. M. No. Ir3212, where the court announced in its finding that the evidence was insufficient to justify a finding of guilty or acquittal, and therefore instructed the judge advocate and counsel for accused to ask a continuance.

${ }^{23}$ Changes, Manual for Courts-Martial, No. 5, July 14, I919, par. 94.

${ }^{24}$ O'Brien, Military Law and Courts-Martial (1846) 236. I Winthrop, op. cit, 226.
} 
it shall be to act as counsel for all accused persons tried by that court except those who have counsel of their own selection. In this latter case, the defence counsel may, by mutual agreement between himself and counsel selected by the accused, act as associate counsel. Officers so detailed should have the qualifications described in paragraph 94 for judge advocates, and should be selected with the same care."

This paragraph establishes the first standard of qualifications for the accused's counsel, ${ }^{25}$ and seeks to put him on the same plane with the trial judge advocate.

The facts are, then, that there is imposed upon a body of officers without legal learning and without legal experience the duty not only of determining disputed questions of fact and applying to the facts so found undisputed principles of law but also of deciding questions of law, often technical and complex; and this, without the assistance of any official corresponding to the nisi prius judge and without the aid of skilled counsel for the parties. With but little more legal or judicial qualifications than the average jury, they are required to perform the functions of both judge and jury without the help even of learned counsel.

The control of the appointing and other superior military authority over the court and its findings is to the civilian the most astonishing and confusing characteristic of the court-martial system. The number of officers, between the statutory maximum and statutory minimum, to be detailed to a general or special court is determined by the appointing authority, whose decision thereon is final. ${ }^{26}$ Even during the trial of a case, either he or superior military authority may relieve an officer from service with the court and order him to other duty. So long as the court is not thereby reduced below the required minimum, it may continue to function, so that a general court might begin the consideration of a case with thirteen members and end with five. The appointing authority may, during the trial, add new members, if

\footnotetext{
${ }^{25}$ The ignorance of counsel and his failure to realize the tremendous responsibilities of his position, as revealed in some of the cases, are truly astounding. In C. M. No. II7I74, where accused was on trial for the capital offense of desertion, the value of the services of his counsel is evidenced by counsel's statement:

"In view of the fact that I have had no opportunity to investigate the charges against the prisoner, I would like for the court to let him go on the stand and make an unsworn statement in his behalf."

In C. M. Nos. I21043 and 123826 the defence of mental irresponsibility was not even suggested, though the accused in each case was, in fact, an imbecile. In C. M. No. rr9330 accused, on trial for desertion, was evidently of very low mental calibre. Counsel, a chaplain, instead of relying upon the defence of mental incapacity, complacently informed the court that he did not believe in sending men before "nut boards," i. e., boards of psychiatry, for such mentally irresponsible soldiers "should either be emasculated or sent to Leavenworth." In all these cases the accused were convicted.

${ }^{23}$ Martin v. Mott (r827, U. S.) I2 Wheat. 19, 34, 6 L. ed. 537.
} 
the membership of the court is not thereby increased beyond the statutory maximum. Even though the court be reduced below the minimum, it is not thereby dissolved, and the appointing authority may add sufficient members to constitute a legal court. Although this practice of adding new members is discountenanced by the Manual for Courts-Martial ${ }^{27}$ and by some military writers, ${ }^{28}$ the validity of the proceedings are not affected by such addition, if opportunity is given the accused to challenge the new members, and the proceedings theretofore had are read over to them in open court. ${ }^{29}$ Conceivably, therefore, the entire membership of the court might be changed by the appointing authority during the progress of the trial, so that not a single member of the original court would participate in the finding and sentence. Thus the membership of the court, both as to numbers within statutory limits and as to personnel, is entirely within the control of the appointing or superior military authority at all times.

And almost the same thing is true of the finding and sentence of the court. By express statutory provision, the approval of the officer appointing the court or his successor in command is a condition precedent to the execution of any sentence $;^{30}$ and by virtue of this power of approval, he may approve or disapprove a finding, or approve only so much of a finding of guilty of a particular offense as includes a finding of guilty of a lesser included offense, and may approve or disapprove the whole or any part of a sentence. ${ }^{31}$ Where a sentence requires confirmation by higher authority, this authority may exercise similar powers over finding and sentence. ${ }^{32}$ Furthermore the appointing authority may, by the customs of the service, return the record in any case to the court for reconsideration and revision. His power so to do is firmly established in the English and American court-martial systems, and has been exercised in this country without serious question for more than a hundred years. ${ }^{33}$ The exercise of this power has recently been confused with the power to order a new trial and has been alleged to be unconstitutional. ${ }^{34}$ Both the constitutional

${ }^{2 \pi}$ Par. 7.

$\approx$ O'Brien, op. cit., 260.

$\approx$ C. M. No. 106486, Nov. 22, I9I7; I Winthrop op. cit., 91-92, 234-236.

$\Rightarrow$ A. W. 46 .

${ }^{31}$ A. W. 47 .

A. W. $48,49$.

${ }^{33}$ Kennedy, Military Law (1847) 212; McArthur, Naval and Military Courts Martial (I813) I36; Simmons, Court Martial (1875) 298; Tytler, Essay an Military Law (1806) I69, 338; Benet, Military Law and Courts-Martial (I868) I69; De Hart, Military Law (1862) 203; Macomb, Martial Law and CourtsMartial (I809) 32; O'Brien, op. cit., 277-280; I Winthrop, op. cit., 643-649; Dig. Ops. J. A. G. (1912) 170, 568; C. M. No. 113886.

${ }^{3}$ See Andrew A. Bruce Double Jeopardy and The Power of Revicu in Court Martial Proceedings (rgI9) 3 MINN. L. Rev. 484-509. Judge Bruce was a member of the special Committee on Military Law of the American Bar Asso- 
provision against double jeopardy and the 4oth Article of War forbid a second trial for the same offense; but revision is in no sense and in no aspect a second trial. The first trial is not completed until the appointing authority has acted. ${ }^{35}$ Nor can it be properly argued that if a nisi prius judge has no rightful authority to refuse to receive a verdict of a jury in a criminal case and to send the jury back for reconsideration, the same must be true as between the appointing authority and the court-martial. ${ }^{36}$ The relation of court to jury does not now, and did not, at the time of the adoption of our constitution or at any other time, exist, between the appointing authority and the court-martial; and no sound argument can be based upon so false an analogy. The fact that the original finding was an acquittal, or that the original sentence was lenient, and the action of the court upon revision was less favorable to the accused does not invalidate the revised finding or sentence. ${ }^{37}$ But the recent astonishment and indignation of civilians upon discovering the existence and exercise of a power so foreign to the usual system of administering justice in the ordinary criminal courts, and the consequent agitation for court-martial reform have led to the issuance of a general order effective August Io, Igrg, abolishing the power to return a finding of acquittal for reconsideration

ciation, and in presenting the report of the majority of the Committee at the meeting of the Association at Boston took the same position as in the above mentioned article. With due deference it is submitted that Judge Bruce has confused new trial and revision, that in quoting the text-writers on Military law as denying the power to revise, he has limited himself to their consideration of the question of new trial and omitted to notice their equally positive assertions of the power to return cases for revision; and that he has mistakenly relied upon false analogies to civil procedure and upon General Crowder's misleading characterization of the appointing authority's action upon the case as a first appellate stage. See note 36 , infra.

${ }^{35}$ Dig. Ops. J. A. G. (Igr2) I70.

"This revision is obviously founded upon the long established practice of Courts of Law where it is competent for the judge to direct the jury to reconsider their verdict. For Chitty states, 'If the jury through mistake, or evident partiality, deliver an improper verdict, the Court may, before it is recorded, desire them to reconsider it, and recommend an alteration. Thus when the decision is repugnant, as if they find one guilty alone of a conspiracy, and acquit the other, they will, on an explanation that they cannot find that one person alone was guilty of a conspiracy, withdraw, and may, on reconsideration, find both defendants guilty. But it is considered as bearing too hard on the prisoner, and has been seldom done in modern times, when the decision is in his favor.' (citing I Chitty, Criminal Laze, 647). The necessity, however, there is for strictly preserving military discipline, and preventing the establishment of precedents that might prove prejudicial to it, does not admit in the Army of such lenity being extended to a prisoner. Courts-Martial also, are often too favorably inclined towards the prisoner, and thus the most frequent grounds upon which a revision is directed, are either an acquittal contrary to evidence, or the inadequacy or illegality of the punishment awarded." Kennedy, op. cit.,

${ }^{37}$ See notes, 33, 36, supra; Cases cited in Report of Hearings before the Committee on Military Affairs (1919) U. S. Senate, 65th Cong. 3d sess., on S. $5320,249-254,255-266$. 
or any sentence for revision upward. ${ }^{38}$ A revocation of this order would, of course, restore the former practice.

The proceedings of the court are subject to no judicial review for the correction of errors. The only review is by the appointing authority or superior military authority, who may have the benefit of legal advice from officers of the Judge Advocate General's Department.

As just indicated, the record of the proceedings of a court-martial, general or special, must be submitted to the appointing authority for his action. This action he does not usually take until after obtaining the advice of his staff judge advocate thereon, as to the regularity and sufficiency of the proceedings, finding and sentence. If the record upon examination shows omissions, interpolations or irregularities, which are capable of correction as being mere clerical errors or as being contrary to the facts actually occurring at the trial, the appointing authority sends it back to the court with directions to reconvene and make the necessary corrections. On such reconvention, the court is strictly limited to making the record conform to the facts. ${ }^{39}$ With the qualifications above noted, the court may also be required to reconsider its finding and sentence. Under no circumstances may the reconvening court receive additional testimony or put into the record matter not theretofore actually before it. ${ }^{40}$

When the record conforms to the facts but contains errors and irregularities prejudicial to the substantial rights of the accused, the appointing authority will usually be advised by his staff judge advocate to disapprove the finding and sentence. This advice he will ordinarily follow, but he is not required to do so. And except where the statute requires confirmation by higher authority ${ }^{41}$ or where the entire proceeding is coram non judice, this action is final, and no higher authority, military or otherwise, can interfere with it. The only relief for the accused thereafter is by way of clemency. Where confirmation is

"G. O. No. 88, W. D. sec. I, July I4, rgI9 reads as follows:

"The following rule of procedure prescribed by the President, modifying the existing procedure respecting the return of proceedings to courts-martial for revision, is published for the information and guidance of all concerned:

I. No authority will return a record of trial to any military tribunal for reconsideration of-

a. An acquittal; or

$b$. A finding of not guilty of any specification; or

c. A finding of not guilty of any charge, unless the record shows a finding of guilty on a specification laid under that charge which sufficiently alleges a violation of some article of war; or

$d$. The sentence originally imposed, with a view to increasing its severity, unless such sentence is less than the mandatory sentence fixed by law for the offense or offenses upon which a conviction has been had.

2. No military tribunal in any proceedings on revision shall reconsider its finding or sentence in any particular in which a return of the record of trial for such reconsideration is herein prohibited.

3. This order will be effective from and after August Io, I9I9."

${ }^{\circ}$ C. M. Nos. II0005, II2702, II5526.

${ }^{\bullet}$ C. M. Nos. 107466, I14904, 127521.

"For cases where confirmation is required see A. W. 48. 
required by higher authority, but not by the President, ${ }^{42}$ the same is true as to the action of the confirming authority.

Where confirmation is required by the President, or where the authority competent to order the execution of the sentence desires to ascertain the pleasure of the President under the 5Ist Article of War, the records go, either directly or through The Adjutant General, to the office of the Judge Advocate General, who reviews them, in order to advise the President what action he should take thereon. By the terms of General Order Nos. 7 and 84, W. D., I9I8, authorities competent to order the execution of sentences involving death, dismissal, or dishonorable discharge were required, before so ordering, to obtain the opinion of the Judge Advocate General or of the Acting Judge Advocate General for the American Expeditionary Forces as to the legality of finding and sentence. In such cases the records are transmitted to the Judge Advocate General or Acting Judge Advocate General, American Expeditionary Forces for opinion prior to final action by the appointing authorities. The President and the appointing authorities respectively usually follow the advice of the Judge Advocate General, but they are not obliged so to do, and in some instances they do disregard it. ${ }^{43}$ It must be understood that the Judge Advocate Gen-

\footnotetext{
2 In time of war sentences of dismissal of officers below grade of brigadier general and sentences of death for murder, rape, mutiny, desertion, and spying.

${ }^{43}$ The notorious Tapalina case, which came to the Judge Advocate General under G. O. 7, presents a flagrant example. Tapalina, a military policeman, was charged with burglary. The court found him not guilty. The appointing authority sent the case back for revision by an indorsement which amounted to an argument that the evidence warranted a finding of guilty. On revision Tapalina was found guilty. The officer reviewing the case in the office of the Judge Advocate General, in par. I8 of the review said:
}

"After a careful consideration of the evidence this office is firmly convinced of the absolute innocence of the accused. The evidence against him is wholly inconclusive, and his own statements have a ring of sincerity which convinces the reader that he speaks the truth."

This review was sent to the appointing authority for his consideration, and he was reminded that the guilt of the accused must be established beyond reasonable doubt, that the Judge Advocate General's office had grave doubts as to Tapalina's guilt, and that the court apparently shared those doubts, as evidenced by its first finding. Nevertheless the appointing authority approved the conviction. Tapalina's seritence was dishonorable discharge and five years confinement in the penitentiary.

The War Department's public justification of this proceeding may be found over the signature of Gen. E. H. Crowder in the official publication, Military Justice During the War (I919) 9, Io. Under date of February 12, 1919, upon application for clemency in behalf of Tapalina, an indorsement was sent, over the signature of Gen. Crowder, to The Adjutant General, which contained the following:

"While it cannot be said that there is no evidence upon which the finding of guilty can be based, this office is strongly of the opinion that an injustice may have been done to this man, and that it should be righted as far as possible. It will be noted that Mr. Flagler, field director of the Red Cross at Camp Gordon, 
eral's opinion does not go directly to the President, but is transmitted through the Chief of Staff and the Secretary of War, who submit their recommendations thereon. The system then is clearly one of review by superior military authority, which may, but need not, ask or follow the opinion of legal advisers, and is in no respect judicial.

It is true that section I 99 of the United States Revised Statutes, I878, provides that

"the Judge-Advocate-General shall receive, revise and cause to be recorded the proceedings of all courts-martial, courts of inquiry and military commissions."

As an original question, it would seem that this statute, reasonably construed, confers upon the Judge Advocate General the power to affirm, modify or reverse, the findings and sentences of courts-martial on account of errors of law. The legislative history of the act tends to show that the Bureau of Military Justice, now merged in the Judge Advocate General's Department, was intended to be a court of military appeals, in which the judgments of courts-martial were to be reviewed, and, if improper, revised. ${ }^{44}$ This Bureau was established at a time when the Army was composed largely of civilians, and when the attention of Congress must have been challenged by the civilian idea that there should be a review by a judicial tribunal of convictions for offenses.

The statute is remedial in its nature and should be liberally construed to overcome the contemplated or existing danger, which clearly is, that well considered justice may not be meted out as the result of trials necessarily held under adverse conditions by untrained and unskilled investigators, whose action is supervised only by a busy military officer, whose business is arms. ${ }^{45}$ The words, "review" and "revise," have been and are frequently used in legislation to describe the functions of an appellate court, including those of affirming, modifying and reversing judgments of inferior tribunals." The words, "re-

comments upon the poor reputation of one of the principal witnesses against Tapalina. It is recommended that the unexecuted portion of the sentence in this case be remitted, and that the prisoner be released from confinement and restored to duty upon his written application to that end."

The contrast between the recommendations of the Judge Advocate General to the appointing authority and to The Adjutant General and the published justification of the conviction, is both interesting and instructive.

"I2 Stat. at L. 598; I3 Stat. at L. I45; I4 Stat. at L. 334; 23 Stat. at L. II3; Cong. Globe 4, 39th Cong. Ist sess. 3672-3676.

${ }^{45}$ For a convincing statement upon this proposition see brief of Col. Eugene Wambaugh, printed as Exhibit $\mathrm{E}$ on $\mathrm{p} .60$ of the Report of Hearings etc. mentioned in note 37 , supra.

${ }^{13}$ See I1l. Const. I8I8, sec. 24; Calif. Const. I879, art. Io; Ala. Const. 1819, sec. 3 ; U. S. Rev. St. 1878, 27I ; Stat. at L. 207; U. S. Rev. St. 1878, 4914; Ariz. Code, I9r3, sec. 330; 2 Ida. Code, Ig08, sec. 4824; 2 Mont. Code, I907, sec. 7096. 
view" and "revise," have for a long time had a definite meaning in military law, a meaning much more broad and comprehensive than that given them in ordinary language. ${ }^{47}$

However, from the time of the passage of the Act, the administrative interpretation of it by the War Department has been that it conferred no real revisory power, but at most authorized the Judge Advocate General to advise proper military authority as to matters of substance and to make clerical corrections. This interpretation has also the support of a dictum of the Circuit Court of the United States, Northern District of New York. ${ }^{48}$ It was affirmed by the present Secretary of War after a full presentation of both sides of the question..$^{40}$

It therefore seems too clear for argument that the principle at the foundation of the existing system is the supremacy of military command. To maintain that principle, military command dominates and controls the proceeding from its initiation to the final execution of the sentence. While the actual trial has the semblance of a judicial proceeding and is required to be conducted pursuant to the forms of law, in its essence it is a mere administrative investigation; for the final determination whether the trial has been legally and properly conducted lies not with a judicial body or officer but with the military. In truth and in fact, under the system as administered by the War Department, courts-martial are exactly what Colonel Winthrop has asserted them to be, namely,

"simply instrumentalities of the executive power provided by Congress for the President as commander-in-chief to aid him in properly commanding the army and navy and enforcing discipline therein and utilized under his orders or those of his authorized military representatives." 50

To be sure, the United States Supreme Court has held otherwise, saying that a court-martial is a court of special and limited jurisdiction, and approving the following statement of Attorney General Bates:

"The whole proceeding from its inception is judicial. The trial, finding and sentence are the solemn acts of a court organized and conducted under the authority of and according to the prescribed forms of law. It sits to pass upon the most sacred questions of human rights that are ever placed on trial in a court of justice; rights which, in the very nature of things, can neither be exposed to danger nor subjected

\footnotetext{
${ }^{47}$ See authorities cited in note 33 , supra, and Col. Wambaugh's brief cited note 45 , supra.

"In re Mason, unreported. The Judge Advocate General had not purported to reverse the finding of the court-martial, and this was the ratio decidendi of this point in the case. The dictum that the Judge Advocate General had no power to reverse is patently ill-considered.

${ }^{4}$ See Report of Hearings, etc., supra, 65

${ }^{5}$ I Winthrop, op. cit., 53 .
} 
to the uncontrolled will of any man, but which must be adjudged according to law." 51

But so long as the court-martial, which, for this purpose includes reviewing and confirming authorities, does not exceed its special and limited jurisdiction, the civil courts are without power to interfere with its proceedings, findings or sentence. ${ }^{52}$ Consequently the military theory prevails and will continue to prevail until changed by legislation.

THE ANSELL ARMY ARTICLES

Such legislation is now pending before Congress. Senate Bill 64 , which has also been introduced in the House of Representatives, ${ }^{53}$ will, if enacted into law, completely revolutionize the court-martial system. $^{54}$ Many of the evils which it was designed to mitigate or prevent have already been recognized by the War Department, which has issued regulations intended to remedy or obviate them, ${ }^{55}$ without, however, surrendering or even materially impairing the military theory of the character and functions of military tribunals.

The procedure for preferring charges and bringing the accused to trial, the bill does not purport to regulate in detail, but it does establish safeguards against the preferring of unfounded charges and against the reference for trial and trial of charges insufficient in law and incapable of being honestly maintained in fact. Article 18 requires every charge to be supported by the oath of a person subject to military law, ${ }^{50}$ either that the affiant has personal knowledge of the truth of the matters set forth or that he has personally investigated them and believes them to be true. No charge may be referred to a general or special court for trial or forwarded to superior authority with a view to trial until after a thorough investigation. Before ordering a trial the appointing authority must be satisfied that the charge can be sustained and cannot, in the interests of justice and of the service, be disposed of without trial. ${ }^{57}$ Article 20 makes a significant change in the existing procedure. It provides:

"No charge shall be referred to or be tried by a general court unless an officer of the Judge Advocate General's department charged. with

\footnotetext{
${ }^{51}$ Runkle v. United States (1887) I22 U. S. 543, 557, 7 Sup. Ct. rI4I. See also Grafton $v$. Urited States (1907) 206 U. S. 333, 27 Sup. Ct. 749.

${ }^{52}$ Swain v. United States (I897) I65 U. S. 553, I7 Sup. Ct. 448.

${ }^{63}$ H. R. 367, 66th Cong. Ist sess.

" This bill was prepared by Gen. Samuel T. Ansell at the direction of the Secretary of War. It was introduced in the Senate by Senator Chamberlain and in the Fouse by Congressman Royal Johnson, not, however, at the request of the Secretary of War or of the War Department.

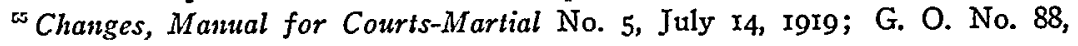
W. D. July I4, I9rg.

This permits a soldier as well as an officer to prefer charges.

"T Art. I9.
} 
such duty shall have indorsed in writing upon the charge that in his opinion an offense made punishable by these articles is charged with legal sufficiency against the accused and that it has been made to appear to him that there is prima facie proof that the accused is guilty of the offense charged."

This makes the decision of a law officer final upon a question of law, and binding even upon the military commander. Failure to comply with it or with other provisions governing the preliminary investigation is punishable by confinement for not more than six months. ${ }^{58}$

The provisions of the present 7oth Article of War requiring that service of charges be made and trial be had within specified periods after arrest are retained in proposed Article 69, with these radical changes: (I) The officer holding the accused in custody must, under penalty, release him upon the expiration of the prescribed period. (2) The accused so released may not thereafter be tried for the crime or offense upon which he was placed in arrest or confinement. ${ }^{59}$

The guaranties of impartiality of appointing authority and court are made quite as adequate as are those affecting judge and jury in the civil courts. A soldier is made competent to serve on a general or special court. ${ }^{80}$ In cases where a private or non commissioned officer is on trial before a general court, three-eighths of the court must be privates or noncommissioned officers respectively. ${ }^{61}$ With special courts, the proportion is one-third. ${ }^{2}$ The concurrence of three-fourths of the members of a general court and of two-thirds of the members of a special court, respectively, are required to convict of any offense. ${ }^{63}$ Ample provision is made for challenge in Article 23:

"An accused before a general court shall have the right to two peremptory challenges and before a special court to one peremptory challenge; and he shall have the right to challenge members of a general or special court for cause stated, which shall include the grounds for principal challenge and challenge to the favor as recognized at common law. If the accused shall file in the proceedings an affidavit of prejudice, accompanied by a certificate of counsel of record that such affidavit is made in good faith, alleging specific grounds to show that the officer appointing the court has bias or prejudice against him, or that the court, by reason of any matter touching its constitution or composition, can not do justice, the court shall proceed no further until the judge advocate shall decide whether it is able to proceed with absolute impartiality in the pending case; and if he decides that the

\footnotetext{
${ }^{6}$ Art. 69.

${ }^{w}$ It would seem that if so serious a consequence is to follow non-compliance, the period for serving charges, eight days, and the period within which trial must be had, forty days, should be materially increased.

${ }^{\infty}$ Art. 4.

${ }^{2}$ Art. 5.

${ }^{2}$ Art. 6.

${ }^{\infty}$ Art. 46.
} 
court can not proceed with absolute impartiality, the court shall not be competent for the trial of the pending case, and he shall so report to the appointing authority; thereupon the next superior authority may appoint a court for the trial of said case. And whenever an accused shall file a like affidavit alleging bias or prejudice of the judge advocate, such judge advocate shall proceed no further in the case, but another shall be appointed."

The provisions for assuring a fair and thorough presentation of the facts and applicable law are far reaching, and, if adopted, will result in establishing a trial tribunal with officials and functions exactly analagous to those of the civil courts for the trial of criminal causes. A trial judge, called the court judge advocate, is.required to be appointed for each general or special court. ${ }^{64}$ The appointee for a general court must be an officer of the Judge Advocate General's Department, except where no such officer is available, in which event he must be an officer recommended by the Judge Advocate General as specifically qualified by reason of legal learning and experience. For a special court he may be either an officer of the Judge Advocate General's Department or that available officer of the command whom the appointing authority deems best qualified for duty on account of legal learning or aptitude and judicial temperament. The judge advocate is not a member of the court, but sits with it at all times in open session and must fairly, impartially and judicially perform the following duties:

"Organize the court from those on or added to the panel designated by the appointing authority for the purpose;

"Rule upon all questions of law properly arising in the proceedings, including challenges and questions touching the competency and impartiality of the court;

"Advise the court and the convening authority of any legal deficiency in the constitution and composition of the court or in the charge before it for trial;

"At the conclusion of the case and before the court proceeds to deliberate upon the finding, sum up the evidence in the case and discuss the law applicable to it, unless both he and the court consider it unnecessary;

"Take care that the accused does not suffer any disadvantage in consequence of his position as such, or of his ignorance or incapacity, and for that purpose the judge advocate may call and examine such witnesses as may appear to him necessary or desirable to elicit the truth;

"Approve of finding of guilty and approve only so much of a finding of guilty of a particular offense as involves a finding of guilty of a lesser included offense, when as a matter of law the evidence of record requires such action; and such action shall be held to be the action of the court;

Art. I2. 
"Announce the findings of the court-martial and upon conviction of the accused impose sentence upon him.

"Suspend [in a proper case] in whole or in part any sentence imposed that does not extend to death or dismissal."

$\mathrm{He}$ also rules upon requests for continuances, ${ }^{65}$ and issues process to obtain witnesses. ${ }^{66}$

The court is bound to accept his advice and follow his rulings made in the performance of these duties. It performs the functions of the ordinary jury. It determines the guilt or innocence of the accused according to the law and the evidence. ${ }^{67}$ It does not pass upon questions of law, nor does it impose sentence.

The prosecution. is conducted by a prosecutor, appointed by the appointing authority, who may appoint either an officer of the Judge Advocate General's Department or an officer or enlisted man deemed by him specially qualified for the duty.

The rights of accused with respect to counsel are, in Article 22, thus assured:

"In all court proceedings, except a summary court, the accused shall have the assistance of and be represented by military counsel of his own selection, and he may have the like assistance of civil counsel if he so provides. Such civil counsel shall be civilian lawyers and such military counsel shall be officers or soldiers; and any officer or soldier under command of the appointing authority who shall be selected by the accused shall be assigned as counsel unless the appointing authority shall furnish the court with a certificate which shall be placed in the record that such assignment can not be made without serious injury to the service and setting forth the reasons therefor. If military counsel be not selected by the accused, the appointing authority shall assign as military counsel to assist in his defence an officer who is well qualified as to rank and experience in the service and who has, if any such there be within the command, special learning in or aptitude for the law.

"In any case before a general court in which the accused is without civil counsel and in which he shall make it appear to the judge advocate that he needs, but is without available means to procure, the assistance of civil counsel, the judge advocate shall employ civil counsel, whereever it is practicable so to do, and fix the amount of compensation for his services, which shall be paid out of any funds available for the purpose; and if the trial shall result in a lawful conviction, the judge advocate may order that the Government be reimbursed by a stoppage of such amount, or any part thereof, against the pay of accused at the rate of two-thirds of his monthly pay until the amount ordered stopped be paid."

Except in so far as Congress otherwise prescribes, the rules of evidence generally applied in the trial of criminal cases in the District courts of the United States are to govern. ${ }^{\text {s }}$

$\approx$ Art. 25 .

${ }^{68}$ Art. 27.

${ }^{o r}$ See Art. 24, for form of oath of court.

${ }^{c}$ Art. 4I. 
The control of the appointing and other superior military authority over the court and the findings is almost completely eliminated. The appointing authority of a general or special court selects a panel of officers whom he deems fair and impartial, from which the court is chosen and organized by the court judge advocate. ${ }^{69}$ The number constituting a general court is fixed at eight; a special court at three. This method of choosing the triers of fact, and the fixing of their number, greatly lessen the danger that the court will be packed originally, or by later orders of the appointing or other superior military authority, relieving members of the court from service thereon and transferring them to other duties. Neither the appointing authority nor any other superior military authority is empowered to review or control in any way the finding of a court, though a sentence of death may not be carried into effect until confirmed and ordered executed by the President, ${ }^{70}$ and the appointing authority may mitigate, remit or suspend certain sentences. ${ }^{71}$ Reconsideration of an acquittal is expressly forbidden. ${ }^{72}$

The proceedings of the trial tribunal are subject to judicial review for the correction of errors. The $52 \mathrm{~d}$ Article of the proposed bill provides:

"There is hereby created a court of military appeals which, for convenience of administration only, shall be located in the Office of the Judge Advocate General, and which shall consist of three judges appointed by the President by and with the advice and consent of the Senate, each of whom shall be learned in the law, shall hold office during good behavior, and shall have the pay and emoluments, including the privilege of resignation and retirement upon pay, of a circuit judge of the United States. Unless the accused when sentence is pronounced upon him shall make the statement in open court that he does not desire that his case be reviewed by the court of military appeals, which statement shall be made a matter of record by the judge advocate, or unless he shall thereafter notify said court of appeals in writing that he does not wish his case reviewed, said court shall review the record of the proceedings of every general court or military commission which carries a sentence involving death, dismissal, or dishonorable discharge, or confinement for a period of more than six months, for the correction of errors of law evidenced by the record and injuriously affecting the substantial rights of an accused, without regard to whether such errors were made the subject of objection or exception at the trial; and such power of review shall include the power-

"(a) To disapprove a finding of guilty and approve only so much of a finding of guilty of a particular offense as involves a finding of guilty of a lesser included offense;

"(b) To disapprove the whole or any part of a sentence;

\footnotetext{
क Arts. 10, 12.

${ }^{70}$ Art. 49 . Art. 38 omits the reference contained in existing Art. 35 to the final action by the appointing authority.

${ }^{11}$ Art. 50.

Art. 34
} 
"(c) To advise the proper convening or confirming authority of the further proceedings that may and should be had, if any, upon the disapproval of the whole of a sentence; and in any case in which all the findings and the sentence are disapproved because of such error of law in the proceedings the appointing authority may lawfully order a new trial by another court;

"(d) To make a report to the Secretary of War for transmission to the President, recommending clemency in any case in which the sentence, though valid, shall appear to the court to be unjust or unduly severe.

"Said judges may select the presiding judge of the court and may prescribe its rules and procedure. In case any judge shall become temporarily incapacitated for the performance of his duties the President, at the request of the court, may assign to duty upon the court a judge advocate deemed qualified for such duty, who upon assignment and taking the oath of office shall have the power and shall perform the duties of a judge of said court, and the Judge Advocate General shall assign to duty with the court such officers, enlisted men, and civilian employees in the Judge Advocate General's Department as the court may find necessary for the thorough and expeditious performance of its duties.

"Each judge before entering upon the duties of his office shall take the oath prescribed for the judge advocate of a general court."'73

There is thus provided an automatic appeal in the cases specified. Errors not made the subject of exceptions are to be noticed by the court, because under the circumstances surrounding military trials, experienced counsel cannot usually be obtained; but only such errors as injuriously affect the substantial rights of the accused furnish grounds for reversal. ${ }^{74} \mathrm{New}$ trials are expressly authorized, and the objection thereto based upon the prohibition against double jeopardy is obviated by the provision enabling the accused to prevent the review, if he so desires. A similar review by a judge advocate for errors of law prejudicial to the accused is provided for in Article 39 in cases tried by special and summary courts.

The bill makes many other notable changes in the existing military

\footnotetext{
${ }^{73}$ This article concludes as follows:

"And said court of military appeals shall have like jurisdiction to review and revise any sentence of death, dismissal, or dishonorable discharge approved for any offense committed and tried since the 6th day of April, r9I7, and any sentence of death, dismissal, or discharge in the case of any person now serving confinement as a result of such sentence upon application to that end made by the accused within six months after the passage of this act: Provided, That no case in which the sentence has heretofore been approved shall be tried again: And provided further, That the revision or reversal of the sentence in any such case shall not be effective to retain in the military service any person who has been dismissed or discharged therefrom in execution of such sentence thus reviewed or to entitle any person to any pay or allowances, but shall be limited in its effect to the final determination that the separation from the service was honorable instead of dishonorable."

"Art. 40; A. W. 37.
} 
code. Offenses are defined, particularly the serious military offenses, such as desertion ${ }^{75}$ and mutiny, ${ }^{76}$ where the element of intent is controlling; punishments are prescribed within definite and reasonable limits for time of war and time of peace $;^{77}$ the general article, denouncing conduct prejudicial to good order and military discipline, is limited so as to apply only to minor infractions of discipline ${ }^{78}$ the records of and reports upon the proceedings of all courts-martial and military commissions, wherever filed, are made public records and as such subject to public examination $;^{79}$ and inconsistencies and uncertainties in the present article are remedied.

Obviously the basic principle of this bill is the very antithesis of that of the existing court-martial system. The theory upon which this bill is framed is that the tribunal erected by Congress for the determination of the guilt or innocence of a person subject to military law is a court, that its proceedings from beginning to end are judicial, and that the questions properly submitted to it are to be judicially determined. $^{80}$ As the civil judiciary is free from the control of the

${ }^{75}$ Arts. 53, 55.

${ }^{70}$ Art. 65.

"Arts. 44, 45, 47, 48, 53-97.

${ }^{78}$ Art. 96.

${ }^{\text {To Art. } 5 \text { I. }}$

s Gen. Ansell's statement of the principle and purpose of the bill follows:

"The primary principle of this bill is to establish Military Justice and regulate it by Law, rather than by mere Military Command; or stating it differently, to supersede personal Military Power over Military Justice by Public Law. Law, to be effective for this purpose, must be law in its primary sense-a rule established beyond the control of the Department and the Army which are to administer it.

"Accordingly, this Bill, designed to cure the vices of the existing system and to establish military justice upon the firm foundations indicated, is built upon the following basic considerations:

"(I) It proceeds in furtherance of the fundamental theory that courts-martial are inherently courts, their functions inherently judicial, and that their powers must be judicially exercised, and it discountenances and penalizes a disregard of the sacred character of these judicial duties and functions.

"(2) It requires that the fundamental principles of right and justice declared to be such by our law and established as necessary to a full, fair, and impartial trial, shall be recognized and observed throughout the court-martial proceeding from accusation to execution.

"(3) It abolishes the present intolerable delegations of penal power and instead of leaving the military commander largely at liberty to determine the offense, the punishment, and the procedure, establishes these elements with that definiteness and precision which should characterize the exercise of all penal power.

"(4) It endeavors to provide that military punitive action be buttressed in enlightened concepts of justice, be regulated by the principles of justice, and that it give results that can fairly be accepted as justice.

"(5) It obstructs a hasty resort to punitive methods, withholds the hand of the commander who would be arbitrary, and stays the power of military authority that it may be exercised considerately and guided advisedly.

"(6) It proceeds upon the principle that military authority itself is subject to the demands of justice, and endeavors to reestablish in the Army a respect for, as it requires an observance of, those methods and processes which are necessary to justice.

"(7) It has regard for the fact that our soldiers are citizens; that the military 
executive, so the military judiciary must be untrammelled and uncontrolled in the exercise of its functions by the power of military command. The decision of questions of law and legal rights is not an attribute of military command. Which theory should prevail in a country whose soldiers are citizens and whose citizens in every war must become soldiers?

status is but an incident of citizenship and that to it the rights of the citizen should not be unnecessarily sacrificed.

"(8) It regards grade in the Army as a requisite of authority only, and not as marking a caste with established rights of preferment in matters of justice.

"(9) It abolishes star-chamber methods of court-martial procedure and declares the records to be public records accessible to the public as such." 